\title{
Lesson study as a vehicle for improving SEND teachers' teaching skills
}

\author{
Mona Holmqvist \\ Department of School Development and Leadership, Malmö University, \\ Malmo, Sweden
}

\begin{abstract}
Purpose - Collaborative professional development for inclusive teaching is a limited area of research, although there is an extensive need for special educational needs and disabilities (SEND) teachers. Research findings of how teachers' professional development can contribute to support the development of powerful learning situations for all students are presented in this special issue. The aim is to contribute to the knowledge of how the use of lesson study can develop teachers' capabilities to offer high-quality education for students with SEND.
\end{abstract}

Design/methodology/approach - The guest editor presents each of the papers and introduces key themes and concepts.

Findings - The collection of papers is divided into two themes; the first has a focus on lesson study used by teacher educators during SEND in-service training. In this theme, the teachers are the students who are studying different fields of SEND, supported by teacher educators. The second theme studies different forms of lesson studies carried out by researchers and teachers in the collaboration focused aspects of content that are of importance for students in SEND.

Research limitations/implications - The papers focus on areas of education with a limited research tradition, and as a result, the studies may be seen as starting points for further research. The results so far lack generalisability. Therefore, the researchers have to test the findings further under different conditions and with wider groups of teachers and students.

Practical implications - The results of the papers can be used to develop both SEND teacher education, and collaborative professional development for in-service SEND teachers. This issue will, therefore, be of interest to school and system leaders.

Originality/value - The papers contribute initial findings from an under-researched area and also combine lesson study with methods and designs not previously explored.

Keywords Lesson study, Collaborative professional development, Inclusive education, Special educational needs, Special didactics

Paper type Research paper

\section{Introduction}

Inclusive education is a global goal for teaching (Hunt, 2019), often declared as having an aim to teach all students in mainstream school settings. Brusca-Vega et al. (2014) proposed that in order to be defined as inclusive, at least $40 \%$ of a child's education should be spent in regular classrooms. There is, as a result, an increase in professional development to help teachers to support students who have learning disabilities or difficulties affecting their ability to cope with schoolwork. These difficulties are recognized if they have a significantly greater degree of difficulty than is usually expected for children at that age, in order to ensure that all

(C) Mona Holmqvist. Published by Emerald Publishing Limited. This article is published under the Creative Commons Attribution (CC BY 4.0) licence. Anyone may reproduce, distribute, translate and create derivative works of this article (for both commercial \& non-commercial purposes), subject to full attribution to the original publication and authors. The full terms of this licence may be seen at http:// creativecommons.org/licences/by/4.0/legalcode.

I am grateful for the funding of the graduate school Special Education for Teacher Educators (SET) from the Swedish Research Council (Dnr 2017-06039).

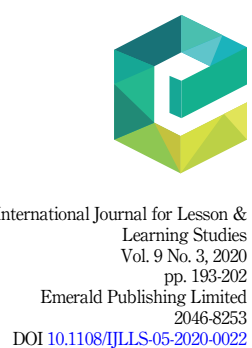


IJLLS

9,3

194

children can be developed to their full potential. Understanding how to address the challenges students meet during their education requires education of and professional development for qualified teachers' to enhance their knowledge of both typical and atypical learning. Unfortunately, many countries struggle with a lack of special educational needs and disabilities (SEND) teachers, which puts children in special educational needs at risk. In Sweden, where the studies presented in this special issue were conducted, more than half of all SEND teachers are expected to retire within the next ten years. To fulfill the need for special education, 1,200 teachers must qualify annually, but so far, only 500-600 do so each year (Holmqvist, 2019). This means vulnerable groups with multiple disabilities are currently already disadvantaged educationally due to the lack of specialist teachers. For instance, Fouganthine (2012) explains that even if many teachers recognize that students have, (in this case, for example,) reading and writing difficulties, they lack specific evidence-based knowledge to support learning and to teach compensatory strategies. And this may be the case in numerous different situations. Every study in this issue, therefore, focuses on how to enhance teachers' professional development in providing support for students with special educational needs in inclusive school settings: a research field, which is currently limited.

Waitoller and Artiles (2013) have published a review of research on professional development for inclusive teaching, including studies from 2000-2009. The results show that of 1,115 articles, only 12 articles were about collaborative professional development for inclusive teaching. A follow-up on their review, Holmqvist and Lelinge (submitted manuscript) shows that even without any time-limit, a search for articles published until 2019 only found 21 studies. This lack of research interest is surprising, as results from the Teaching and Learning International Survey (Opfer, 2016) have reported a significant relationship between teachers' self-efficacy and collaborative professional development, which is also supported in research (Lauermann and König, 2016). Furthermore, the results of the study show that if the teachers participate in in collaborative professional development at least once a week, they also report higher self-efficacy levels than other teachers (OECD, 2014). Lesson study is a collaborative professional development model, which addresses the aspects of importance found in Opfer, 2016, and the content of the studies in this issue would suggest that it should be used more frequently to enhance teachers' knowledge of how to teach students with SEN in inclusive learning settings. Furthermore, the research presented in this issue also aims to show how lesson study can be used somewhat untraditionally, such as studying relational aspects between students and teachers learning in school-age educare and also studies of what aspects are of particular importance during the preparation phase of introducing these teachers to lesson study. A particular problem seen in collaborative professional development is sustainability. Greenwood et al. (2003) show that a weak sustainability was identified after the researchers left the school. These teachers did not increase their use of the new strategies introduced by the researchers. If teachers are not themselves directly involved in defining the problems or have a need for other changes than suggested by the researchers, the project becomes detached from their ordinary work, and as a result, seems less important to continue afterward. As lesson study is based on strong involvement and agency of teachers, it promises to be a model for professional development of SEN teachers that is powerful regarding sustainability. Some studies have already been published, such as Ylonen and Norwich's (2012) study on how to use lesson study to enhance teachers' approaches for secondary students with moderate learning difficulties. The same researchers (Norwich and Ylonen, 2013) evaluated lesson studies in terms of outcomes and found that contextual factors are critical for the sustainability of lesson study in schools. Another research group studying the use of lesson study for an inclusive learning situation is based in the Netherlands. Schipper et al. (2017) have recently presented results of outcomes such as professional growth in adaptive teaching for teachers who have been participating in lesson study projects. 
As enhancing teachers' professional development for all students' learning is the overarching theme of this special issue, the research presented in the articles builds on previous research, and this special issue aims to contribute to our understanding of how the use of lesson study can develop high-quality education for students with special educational needs (SEN). The studies are not oriented in the conventional special education research tradition; instead, it is work in the classroom with the students that are in focus and specifically the didactic perspective. Special Education Didactics focuses teaching and learning in special areas of interest, such as subject areas or development of cross-curricular skills Furthermore, special didactics (didactica specialis) (Kansanen and Meri, 1999) is education specifically for students who, at a certain time or in particular contexts, differ from what is perceived as typical (Borgbjerg Hansen and Degn Mårtensson, 2017). Special didactics focuses on different areas in the relation between teaching and learning and "may relate to problems of teaching in different types of school, to particular age levels of the students or to specific domains of content (subject disciplines)" (Kansanen and Meri, 1999, p. 16). The capability for teachers to teach students with special educational needs requires the development of skills for understanding the special didactic difficulties students can meet in ordinary education. The competence to understand how inclusive education can be designed to meet the needs of different students makes it possible for more students to gain access to knowledge.

As a result of this complex context, the aims of this special issue are to contribute to the knowledge of how SEN teachers' professional knowledge is developed through lesson study with the focus on two themes. The first is on the teachers as students in professional development interventions with researchers as instructors (Plantin Ewe, Leifler and Sjunnesson). The second focus is on a project conducted by a 2013 NASEM study in which teachers experiencing different learning needs in their students and used lesson study diagnose, implement and develop modes of support from different areas of SEND, which is again an area of research in which little work has been done so far (Klefbeck, Lundbäck and Egerhag, and Nilvius).

\section{The context of the conducted studies}

The studies presented in this special issue are conducted by former school teachers, who have also worked as teacher educators at different universities for many years. An application to the Swedish Research Council following an announcement of funding for graduate programs for teacher educators without a PhD, was granted in 2017 (Dnr 2017-06039). In 2018, a total of 12 doctoral students were accepted for this postgraduate study. The students were from four different universities, Malmö university (host), Kristianstad University, Linnaeus University, and Karolinska Institutet. The management group was formed from one professor from each university: Mona Holmqvist (main applicant Malmö University), Jonas Aspelin, Kristianstad University, Peter Karlsson, Linneaus University and Sven Bölte, Karolinska Institutet. More information about the graduate school, Special Education for Teacher Educators (SET), can be retrieved from https://repese.mau.se/set/.

The focus of special education didactics in the graduate school are areas of SEND as defined in the goals for the SEND teacher education. As several reports have found challenges for teachers to teach students with neurodevelopmental conditions (NDC) (approximately $10 \%$ of all students (Boyle et al., 2011)), there is an urgent need to enhance teachers' competence in this area. As a new degree objective for the teacher education program for SEN teachers in Sweden is to enhance teacher education students' knowledge of how to teach this group of students, the need for teacher educators to have developed knowledge about the research in this field has increased. In this special issue, Plantin Ewe has a focus on ADHD in her study, and Leifler on neurodevelopmental conditions (NDC). Three other areas featured 
IJLLS 9,3

are; education for students with intellectual disabilities addressed in Klefbeck's article; mathematical and language special didactics, which is studied by Sjunnesson, Nilvius and Lundbäck and Egerhag.

Another focus of studies in graduate school is models for collaborative professional development (Holmqvist, 2017). In line with the results of Opfer, 2016, Hattie (2012) also points out collaborative professional development close to the teachers' practice as a powerful way to enhance teachers' competence. Taking this into consideration, the research program

for graduate school includes parts where the $\mathrm{PhD}$-students take courses in this area and also conduct studies to develop their own skills to design, implement and analyze outcomes from collaborative professional developmental projects. Some of the results of this are presented in this special issue, as the PhD-students present their collaborative professional development projects in collaboration with SEND teachers.

Feedback to teachers was one of the important aspects found in Opfer (2016) that enhanced teachers' job satisfaction. As a result, a particular focus in this issue is on how teachers give and receive feedback on their own professional knowledge development, as well as on students' knowledge development. Sjunnesson (2020) has targeted the initial phase of a lesson study to examine the process teachers undergo in order to become familiar with having another person observing and commenting on their teaching. In Plantin Ewe's (2020) and Leifler's (2020) studies, the lesson study models are for teachers as students because the teachers are participating in the interventions planned and implemented by groups of teacher educators. In this case, the study of feedback used during the lesson study cycles is prominent.

The three models that the students have studied are improvement science (Lewis, 2015), teaching research groups (Yang, 2009) and learning and lesson studies (Pang and Ling, 2012). The main part of the students used the lesson study model, the results of which are presented in this issue. The intention was that through participation both in these studies and in the implementation of collaborative professional development models, the PhD students, (who also are teacher educators), would develop their readiness to educate future teachers to supervise and guide colleagues improving SEND students' learning. Finally, digitalized teaching is also in focus in graduate school, and in the light of COVID-19, the students have all been practicing how to use digital tools for teaching extensively. Furthermore, the students have used not only video-recorded observations but also digitalized material for pre- and post-test design or tools used for communication (Plantin Ewe, 2020; Sjunnesson, 2020).

\section{Lesson study used as a model for the professional development of SEND teachers' professional knowledge development}

As the studies presented in this special issue aim to challenge and expand the way lesson study is mainly perceived and used, the studies also strive to develop lesson study and strengthen its position by finding new areas possible to develop. One such new way of using lesson study is to work in teams as teacher educators, where the students in these projects are teachers and not pupils or students in ordinary school settings. One such study is by Plantin Ewe (2020), who has conducted a lesson study based on a research review of ADHD symptoms and teacher-student relationships (Plantin Ewe, 2019). The results of the review showed that "teachers' rejection of ADHD students poses a risk-factor for not only school failure, but also peer exclusion and rejection, leading to low self-esteem and loneliness" (Plantin Ewe, 2019, p. 136). By aiming to enhance in-service teachers' relational competence, her lesson study aimed to create a more positive learning situation. Studies have shown that there is a risk of burnout for teachers for students with autism because the teachers have difficulties coping with their behavior (Jennett et al., 2003). The content to be taught was relational competences regarding students' with $\mathrm{ADHD}$. The in-service teachers were, as 
students in ordinary school-settings, taking a pre- and post-test to capture the students' knowledge development. The design of the research lessons and methods used were discussed in the researcher's teacher-team, which consisted of supervisors and doctoral students. The lesson focused on teachers' awareness of verbal and nonverbal communication, and theories, as well as a checklist, were presented for participating teachers in a lecture about relational competence. The pre- and post-test data consisted of reflections on a video-sequence, which were complemented with interviews to further analyze the teachers' knowledge development. The participants reported they had developed their relational understanding, and Plantin Ewe (2020) has shown the effect on using lesson study to teach in-service teachers, and also the use of a video-sequence for analysis as a form of pre- and post-test.

While Plantin Ewe (2020) has used relational competence as the content to be learned, Sjunnesson (2020) has focused on communication and how to prepare in-service teachers' participating in a lesson study. Communication in this study is not at a generic level. Instead, it has a special didactic focus on how to communicate a mathematical content with SEND students; multimodal design and digital storytelling in mathematics (Istenic Starčič et al., 2016). As the research focus in Sjunnesson's (2020) study is on the initiation into lesson study, an interview was conducted with the participating teachers at an early stage. Second, to familiarize the use of the model, one teacher taught a general lesson while the other teacher observed. This was discussed afterward, with reflections from the teachers and the basis for the design of a test lesson. The focus was on how to introduce a lesson study to teachers unfamiliar with this kind of professional development. One important finding is the advantage of using an introduction lesson as a starting point for finding an area of importance to develop, as well as an opportunity to start to define the content to be focused on while designing subsequent research lessons. For teachers familiar with lesson study, it might not be difficult to understand how to implement it and what benefits can be found, but for teachers unfamiliar with this kind of collaborative professional development, the initializing phase became crucial both for the quality of what was developed and also to make powerful the analysis of all the data that have been gathered.

Leifler (2020) has, like Plantin Ewe (2020) and Sjunnesson (2020), also conduct a lesson study for in-service teachers' learning, however not the initial phase as Sjunnesson. Instead, this study consists of three cycles in each group of teachers at three different schools. The duration of the study at each school was five weeks. The focus of the teachers' knowledge development was on their capabilities to adjust the learning environment for increased inclusivity for students with Neurodevelopmental Conditions (NDC), and to gain knowledge in what is important to change, lectures about the conditions were conducted. The lectures were given in a cyclical process, where the teachers followed a model where they were supposed to: (1) Reflect and review, (2) Study/content presentation, (3) Plan for next accommodation, and 4. Prepare and do. As the teachers were not only students in the lesson study cycles, but also practicing their own theoretical studies in their schools and in their classes, the lesson study embedded the classroom practice as a vehicle for verifying the content learned in these interventions. Through this and unlike Plantin Ewe (2020) and Sjunnesson (2020), who did not study the effects of the interventions shown in the teachers' classroom practice, Leifler (2020) used a design where the teachers had opportunities to reflect on changes in their teaching. The changes were studied in three areas; pedagogical, psychosocial, and physical. The most developed was the psychosocial area, including practices such as enhanced additional confirmation, diversions for managing difficult behavior, and involving the interests of students for strengthening desirable behaviors like on-task-focus and motivation. Leifler (2020) points out that participating in this intervention result in teachers becoming better prepared for teaching students with NDC. Their need for further professional development decreased during the intervention. 


\section{IJLLS 9,3}

\section{Results from lesson studies in SEND teacher education and less studied SEND fields}

Three of the articles in this special issue address an expanded use of lesson study in different contexts, or in areas with limited research. Klefbeck (2020) has conducted a lesson study for children with intellectual disabilities (ID). In this study, the students are attending a special school for children with severe SEND, which also means they do not follow the regular curriculum. In other respects, this study followed the most commonly practiced model of lesson study (Makinae, 2010), and the content the students' focused on was quantity and size judgment. The teacher and the researcher worked jointly to enhance the students' learning. One of the findings revealed how a teacher had rather low expectations of one of the students' learning possibilities, but through the use of pre- and post-tests, the teacher became aware of this and the student then developed more than the other students did. The result of the study suggests certain difficulties conducting a lesson study with very heterogeneous groups of students with intellectual disabilities (ID) How to test and design lessons there has to be adjusted to the students' particular abilities, and it is, therefore, difficult to have a group-perspective on the teaching situation as all of the students have very individual needs.

Another area that is under-researched in this field is school-age care in Sweden. This is a kind of after-school activity, however not focusing on school work but on leisure time activities (which, of course, can also involve doing homework). In Sweden, Educare is used to take care of school children up to twelve years old when their parents are at work. In that sense, it is like a pre-school but for older children (aged 7-12 years). It is not mandatory, and parents have to pay a fee for leaving their children at the leisure centers. Usually, the schoolage educare settings are placed close to the school, and in some cases, ordinary classrooms replicate the same physical environment for the school-age educare. The teachers working at the centers have a teacher education; however, it is different from ordinary school teachers. In some cases, it is a combined teacher education involving both leisure time teaching combined with some subject/s for regular school. Lundbäck and Egerhag (2020) have conducted a lesson study with teachers from both contexts, an elementary school and school-age educare to bridge the gap between the children's learning in mathematics in the two different contexts. The result points to advantages for both groups of teachers from the two settings who all found it beneficial to collaborate in a lesson study. The mapping of students' knowledge and understanding was helpful for them to discuss and plan for teaching at school and in supporting activities in the school-age educare center. They even suggested the model should be implemented across the whole school, in spite of the fact that they also found it time consuming.

Finally, Nilvius (2020) has expanded lesson study by merging it with the research method known as Response to Intervention (RTI) in order to enhance the didactical methodological element in assessing students at risk of developing learning difficulties through lesson study. This work is not empirical, but a theoretical analysis first of how to adjust RTI as a tool in lesson study to enhance student learning, and secondly, how RTI can be made more user friendly by teachers in lesson study. At a theoretical level, Nilvius (2020) argues that there are complementary benefits and challenges in each model through which they can complete each other. As RTI is structured and used as a tool to find students at risk of developing learning difficulties, the method can be used in lesson studies to more systematically study students' knowledge development. The results from RTI can point out what difficulties the students have, and by that inform the teachers while planning lessons. On the other hand, as RTI is not user-friendly for teachers, adjusting RTI to the lesson study model where teachers have a great impact in the implementation is seen a beneficial for the method. If the models benefit by being merged has to be tested in the future, but a study from another collaborative professional development project (Rinaldi et al., 2011) have presented results of enhanced sustainability of the use of RTI if teachers are working on equal conditions as the researchers 
with the implementation for the method. In their studies, co-teachers were involved in conducting the different steps in the RTI project.

\section{Conclusions}

The articles in this special issue reveal different and thus far under-explored fields where lesson study can be implemented. Changing the view of what lesson study can be, requires an openness and discussion about what limitations there are and why. Where is the limit passed for what can be defined as a lesson study? Is it the iterative steps that define the model, the collaboration, identifying the knowledge development or the analysis of lesson designs? The examples in this special issue show how lesson study has been used and adjusted to develop actual areas that are challenging teachers' daily work. One prominent track is the use of lesson study in teacher education and in-service training, where the teachers are defined as students, and the knowledge assessed is what the teachers have learned. In some cases, this has been done with digitalized tests or parts of the interventions. The other track consists of a focus on students' learning and the collaboration between researcher and teachers in developing lesson study in fields of limited research; special schools for children with intellectual disorders (Klefbeck, 2020), school-age educare (Lundbäck and Egerhag, 2020) and merging RTI with the lesson study cycle (Nilvius, 2020). As a researcher, I have had a great opportunity to be a part of the work of learning study and variation theory developed by Ference Marton (2014) in Sweden and Lo Mun Ling in Hong Kong (Ling Lo, 2012). I have also been involved in learning study graduate schools for teachers managed by Ulla Runesson Kempe (Runesson et al., 2018) in Sweden and published a synthesis of knowledge outcomes of research conducted by teachers in the graduate school for learning studies (Holmqvist Olander, 2015). As I have been working with lesson/learning study since 2002 (Holmqvist et al., 2007, 2014), I find it both necessary and exiting to adjust the model to different contexts and different fields to follow the changing circumstances schools, teachers, and students are facing.

Therefore, the way we have developed collaborative professional development differs somewhat from how lesson study has been practiced for decades in Japan (National association for the study of educational methods, 2013), where almost all teachers and students seem to be familiar with the model, where, therefore, there might not be so many challenges for implementing or introducing the model for teachers as it is already contextually embedded. However, in contexts where we traditionally have not worked collaboratively in this way in professional development, the lesson study model is challenging both regarding time spent and the observation of lessons for teachers who are not used to being so thoroughly reviewed while teaching. In this special issue, the research presented has a focus on special educational needs, and on enhancing powerful learning situations for all students by enhancing the teachers' competences. Hopefully, these studies will be found to be both innovative and informative in helping people to develop learning settings for all students, without leaving anyone behind, and also hopefully, this will have strong implications for practice.

\subsection{Implications}

The studies in this special issue all indicate different fields where the findings can have an impact on practice. Observing, giving feed-back, which informs revised instruction, is not an ordinary teaching context in the teacher training, no matter if we focus on pre- or in-service training. By that, the results can guide other teacher educators to implement lesson study in their work as future or current teachers. The lectures in Swedish teacher education is rather at a theoretical or abstract level than a methodical or practice focused (Wahlström and 
IJLLS 9,3

\section{0}

Alvunger, 2015). This challenges the ordinary way of how to analyze the students' learning outcomes, and by that, how to design any pre- and post-tests. Another challenge is to what extent the results captured in the lesson study indicate, or not, changes in how teacher educators lecture or design courses. A further implication is the findings of how teachers from different contexts and backgrounds can collaborate to focus on the children's learning. Many lesson studies are conducted by teachers with the same subject interest or from the same social/school context. Maybe this has to be challenged, by merging teachers in different contexts in conducting the same lesson study together, rather than by merely observing each other's lessons. The sustainability and time spent in following the lesson study model is also a challenge. Previous research has pointed out difficulties for professional developmental models to be sustained after a project has finished. One solution is to integrate and try out a tool that helps teachers in daily work, such as RTI, which can motivate teachers and thus enhance sustainability. If the teachers feel they are in need of professional development, it could be assumed that sustainability would increase. Local context affects how this can be solved, and the initialization phase of lesson study implementations in new contexts that are unfamiliar with this kind of professional development does seem to be crucial.

\subsection{Further research}

While much as been achieved in the SEND field of lesson study, the main work still remains to be done. The results presented in this issue are promising, but more has to be done to understand in what way the LS model can be adjusted to serve the needs of pre-and in-service teachers' professional development for students with SEND. Regarding students with severe learning disabilities, as well as students with neuropsychiatric conditions, it is rare to find research results guiding how to develop becoming or current teachers. The teacher educators and $\mathrm{PhDs}$ in the graduate school SET will continue their work in this field, and I hope many other researchers will also do so, to help the students with the greatest needs to develop to their greatest potential.

\section{References}

Borgbjerg Hansen, H. and Degn Mårtensson, B. (red.), (2017), Specialdidaktik $i$ teori og praksis. Undervisning på specialskoler og $i$ specialklasser, Hans Reitzels Forlag, Köpenhamn.

Boyle, C.A., Boulet, S., Schieve, L.A., Cohen, R.A., Blumberg, S.J., Yeargin-Allsopp, M. and Kogan, M.D. (2011), "Trends in the prevalence of developmental disabilities in US children, 1997-2008", Pediatrics, Vol. 127 No. 6, pp. 1034-1042.

Brusca-Vega, R., Alexander, J. and Kamin, C. (2014), "In support of access and inclusion: joint professional development for science and special educators", Global Education Review, Vol. 1 No. 4, pp. 37-52.

Fouganthine, A. (2012), Dyslexia through Life: A Developmental Perspective on Reading and Writing Difficulties, Doctoral dissertation, Stockholm University, Stockholm.

Greenwood, C.R., Tapia, Y., Abbott, M. and Walton, C. (2003), "A building-based case study of evidence-based literacy practices: implementation, reading behavior, and growth in reading fluency, K—4", The Journal of Special Education, Vol. 37 No. 2, pp. 95-110.

Hattie, J. (2012), Visible Learning for Teachers: Maximizing Impact on Learning, Routledge.

Holmqvist, M., Gustavsson, L. and Wernberg, A. (2007), "Generative learning: learning beyond the learning situation”, Educational Action Research, Vol. 15 No. 2, pp. 181-208.

Holmqvist, M., Gustavsson, L. and Wernberg, A. (2014), "Variation theory: an organizing principle to guide design research in education", in Handbook of Design Research Methods in Education, Routledge, New York, pp. 129-148. 
Holmqvist Olander, M. (2015), "Quality indicators for improvement science by teachers as researchers", in Garbett, D. and Owens, A. (Eds), Teaching for Tomorrow Today, Edify, Auckland, pp. 285-293.

Holmqvist, M. (2017), "Models for collaborative professional development for teachers in mathematics", International Journal for Lesson and Learning Studies, Vol. 6 No. 3, pp. 190-201, doi: 10.1108/IJLLS-12-2016-0051.

Improving SEND teachers' teaching skills

Holmqvist, M. (2019), "Lack of qualified teachers: a global challenge for future knowledge development", in Teacher Education in the 21st Century, IntechOpen, London.

Hunt, P.F. (2019), "Inclusive education as global development policy", The SAGE Handbook of Inclusion and Diversity in Education, p. 116.

Istenic Starčič, A., Cotic, M., Solomonides, I. and Volk, M. (2016), "Engaging preservice primary and preprimary school teachers in digital storytelling for the teaching and learning of mathematics", British Journal of Educational Technology, Vol. 47 No. 1, pp. 29-50.

Jennett, H.K., Harris, S.L. and Mesibov, G.B. (2003), "Commitment to philosophy, teacher efficacy, and burnout among teachers of children with autism", Journal of Autism and Developmental Disorders, Vol. 33 No. 6, pp. 583-593.

Kansanen, P. and Meri, M. (1999), "The didactic relation in the teaching-studying-learning process", Didaktik/Fachdidaktik as Science (-s) of the Teaching profession, Vol. 2 No. 1, pp. 107-116.

Klefbeck, K. (2020), "Lesson study for students with intellectual disability", International Journal for Lesson and Learning Studies, Vol. 9 No. 3, pp. 245-259, doi: 10.1108/IJLLS-12-2019-0082.

Lauermann, F. and König, J. (2016), "Teachers' professional competence and wellbeing: understanding the links between general pedagogical knowledge, self-efficacy and burnout", Learning and Instruction, Vol. 45, pp. 9-19.

Leifler, E. (2020), “Teachers' capacity to create inclusive learning environments”, International Journal for Lesson and Learning Studies, Vol. 9 No. 3, pp. 221-244, doi: 10.1108/IJLLS-01-2020-0003.

Lewis, C. (2015), "What is improvement science? Do we need it in education?", Educational Researcher, Vol. 44 No. 1, pp. 54-61.

Ling Lo, M. (2012), "Variation theory and the improvement of teaching and learning", Göteborg: Acta Universitatis Gothoburgensis.

Lundbäck, B. and Egerhag, H. (2020), "Lesson Study as a bridge between two learning contexts", International Journal for Lesson and Learning Studies, Vol. 9 No. 3, pp. 289-299, doi: 10.1108/ IJLLS-02-2020-0006.

Makinae, N. (2010), "The origin of lesson study in Japan”, The 5th East Asia Regional Conference on Mathematics Education: In Search of Excellence in Mathematics Education, Tokyo, Vol. 2, pp. 140-47.

Marton, F. (2014), Necessary Conditions of Learning, Routledge, New York.

National association for the study of educational methods (2013), Lesson Study in Japan, Keisuisha, Hiroshima.

Nilvius, C. (2020), "Merging lesson study and response to intervention", International Journal for Lesson and Learning Studies, Vol. 9 No. 3, pp. 277-288, doi: 10.1108/JJLLS-02-2020-0005.

Norwich, B. and Ylonen, A. (2013), "Design based research to develop the teaching of pupils with moderate learning difficulties (MLD): evaluating lesson study in terms of pupil, teacher and school outcomes", Teaching and Teacher Education, Vol. 34, pp. 162-173.

OECD (2014), TALIS 2013 Results: An International Perspective on Teaching and Learning, OECD Publishing, Paris, doi: 10.1787/9789264196261-en.

Opfer, D. (2016), Conditions and Practices Associated with Teacher Professional Development and its Impact on Instruction in TALIS 2013, OECD.

Pang, M.F. and Ling, L.M. (2012), "Learning study: helping teachers to use theory, develop professionally, and produce new knowledge to be shared", Instructional Science, Vol. 40 No. 3, pp. 589-606. 
IJLLS 9,3

Plantin Ewe, L. (2019), “ADHD symptoms and the teacher-student relationship: a systematic review of literature", Emotional and Behavioural Difficulties, Vol. 24 No. 2, pp. 136-155.

Plantin Ewe, L. (2020), "Enhancing teachers' relational competence: a teacher lesson study", International Journal for Lesson and Learning Studies, Vol. 9 No. 3, pp. 203-219, doi: 10.1108/ IJLLS-12-2019-0081.

Rinaldi, C., Averill, O.H. and Stuart, S. (2011), "Response to intervention: educators' perceptions of a three-year RTI collaborative reform effort in an urban elementary school", Journal of Education, Vol. 191 No. 2, pp. 43-53.

Runesson Kempe, U., Lövström, A. and Hellquist, B. (2018), "Beyond the borders of the local: how 'instructional products' from learning study can be shared and enhance student learning", International Journal for Lesson and Learning Studies, Vol. 7 No. 2, pp. 111-123.

Schipper, T., Goei, S.L., de Vries, S. and van Veen, K. (2017), "Professional growth in adaptive teaching competence as a result of Lesson Study", Teaching and Teacher Education, Vol. 68, pp. 289-303.

Sjunnesson, H. (2020), "Initializing phase of lesson study: communication a special didactic tool in mathematics", International Journal for Lesson and Learning Studies, Vol. 9 No. 3, pp. 261-275, doi: 10.1108/IJLLS-02-2020-0007.

Wahlström, N. and Alvunger, D. (2015), Forskningsbasering av lärarutbildningen: Delrapport frän SKOLFORSK-projektet. [Research Based Teacher Education: Interim Report from the SKOLFORSK Project], The Swedish Research Council, Stockholm.

Waitoller, F. and Artiles, A.J. (2013), “A decade of professional development research for inclusive education: a critical review and notes for a research program", Review of Educational Research, Vol. 83 No. 3, pp. 319-356.

Yang, Y. (2009), "How a Chinese teacher improved classroom teaching in Teaching Research Group: a case study on Pythagoras theorem teaching in Shanghai", ZDM, Vol. 41 No. 3, pp. 279-296.

Ylonen, A. and Norwich, B. (2012), "Using lesson study to develop teaching approaches for secondary school pupils with moderate learning difficulties: teachers' concepts, attitudes and pedagogic strategies”, European Journal of Special Needs Education, Vol. 27 No. 3, pp. 301-317.

\begin{abstract}
About the author
Professor Mona Holmqvist, Malmö University, Department of School Development and Leadership, leads Research Platform of Education and Special Education (RePESE) at the University and is the research leader for the Department of School Development and Leadership at Malmö University. She is also a council member of the World Association of Lesson Studies (WALS), a global association of research on professional development for teachers. Furthermore, she is appointed by the Government as a member of the National Agency for Special Needs Education and Schools (SPSM) Authorities Board. Mona Holmqvist can be contacted at: mona.holmqvist@mau.se
\end{abstract}

For instructions on how to order reprints of this article, please visit our website:

www.emeraldgrouppublishing.com/licensing/reprints.htm

Or contact us for further details: permissions@emeraldinsight.com 